\title{
ANALISA KINERJA KEUANGAN HOTEL PADA HOTEL SAHID KAWANUA MANADO
}

\author{
Efafras Juan Kakinsale ${ }^{1}$, Herman Karamoy ${ }^{2}$, Inggriani Elim ${ }^{3}$ \\ ${ }^{1,2,3}$ Fakultas Ekonomi dan Bisnis, Jurusan Akuntansi, Universitas Sam Ratulangi, Jl. Kampus Bahu, \\ Manado,95115, Indonesia \\ E-mail: juanefafras@gmail.com
}

\begin{abstract}
This study aims to determine and analyze the hotel financial performance of 2017-2018 at the Sahid Kawanua Manado hotel by using Liquidity analysis (the company's ability to meet its short-term obligations), Solvency (the extent to which the company's ability to meet its longterm obligations), and Profitability analysis (looking at the ability the company generates profit) the effect of profitability, liquidity, and solvency on the soundness of the company, the soundness of the company is needed to determine whether the company's financial condition is healthy or not. This can be done by comparing the ratio of the previous year with the current ratio with analysis of liquidity ratios shows how much the company's ability to use its capital to generate profits in a certain period.
\end{abstract}

Keywords: analysis of hotel financial performance; liquidity ratio analysis; solvency ratio analysis; profitability ratio analysis

\section{PENDAHULUAN}

Salah satu sumber informasi yang dapat digunakan adalah dengan menganalisis rasio laporan keuangan. Laporan keuangan merupakan hasil akhir dari proses akuntansi pada suatu periode waktu tertentu yang merupakan hasil pengumpulan dan pengolahan data keuangan yang disajikan dalam bentuk laporan keuangan atau ikhtisar lainnya yang dapat digunakan untuk membantu para pemakainya dalam mengambil keputusan. Kinerja keuangan perusahaan dapat diartikan sebagai prospek atau masa depan, pertumbuhan, dan potensi perkembangan yang baik bagi perusahaan. Informasi kinerja keuangan diperlukan untuk menilai perubahan potensial sumber daya ekonomi, yang mungkin dikendalikan di masa depan dan untuk memprediksi kapasitas produksi dari sumber daya yang ada.

Pimpinan perusahaan atau manajemen erat terkait dengan laporan keuangan yang telah dianalisis, karena hasil tersebut dapat dijadikan sebagai alat dalam pengambilan keputusan yang lebih lanjut untuk masa datang. Dengan menggunakan analisis rasio, berdasarkan data dari laporan keuangan, akan dapat diketahui hasil-hasil finansial yang telah dicapai di waktu-waktu yang lalu, dapat diketahui kelemahan-kelemahan yang dimiliki perusahaan, serta hasil-hasil yang dianggap cukup baik. Hasil analisis historis tersebut sangat penting artinya bagi perbaikan penyusunan rencana yang akan dilakukan di masa akan datang, dengan mengetahui kelemahan-kelemahan yang dimiliki oleh perusahaan, dapat diusahakan perencanaan yang lebih baik demi memperbaiki kelemahan-kelemahan tersebut. Hasil-hasil yang dianggap sudah cukup baik di waktu lampau harus dipertahankan dan ditingkatkan untuk masa-masa mendatang (Tampubolon, 2005).

Evaluasi kinerja keuangan dapat dilakukan dengan menggunakan analisis laporan keuangan, dimana data pokok sebagai masukan dalam analisis ini adalah neraca dan laporan laba rugi. Analisis laporan keuangan memungkinkan manajemen keuangan dan pihak yang berkepentingan untuk mengevaluasi kondisi keuangan dengan cepat, karena penyajian rasiorasio keuangan akan menunjukan kondisi sehat tidaknya suatu perusahaan. Analisis rasio 
menghubungkan unsur-unsur rencana dan laba rugi sehingga dapat menilai efektifitas dan efisiensi perusahaan.

Pelaksanaan penilaian dalam kinerja perusahaan oleh pihak manajemen umumnya hanya melihat dari tingkat fluktuasi atas laba yang diperoleh tanpa melakukan analisis lebih lanjut, akibat yang ditimbulkan dari kebijakan tersebut adalah perusahaan yang mengalami kesulitan untuk menentukan variabel apa yang menyebabkan terjadinya pembentukan keuntungan atau profit yang lebih maksimal. Keadaan tersebut yang menyebabkan perusahaan sering mengambil kebijakan yang kurang tepat untuk mengadakan penilaian atas kinerja yang telah dicapai selama ini. Apabila kondisi tersebut terus terjadi, akan berakibat pihak manajemen mengalami kesulitan dalam menetapkan kebijakan yang akan diambil.

Perkembangan suatu perusahaan tidak lepas dari peran laporan keuangan yaitu dari laporan laba rugi dan neraca atau laporan keuangan lainnya. Dengan kata lain laporan keuangan merupakan alat menentukan atau menilai posisi keuangan suatu perusahaan pada waktu tertentu. Hasil penilaian ini sangat berguna untuk pihak-pihak tertentu yang berhubungan langsung atau bagi mereka yang ingin menanamkan modalnya dalam perusahaan yang bersangkutan. Suatu perusahaan dituntut untuk meningkatkan kinerjanya agar mampu tetap mempertahankan posisi keuangan dalam masa krisis maupun dalam persaingan yang semakin ketat. Prospek bisa dilihat dari tingkat keuntungan (profitabilitas) dan resiko bisa dilihat dari kemungkinan perusahaan mengalami kesulitan keuangan atau mengalami kebangkrutan (Hanafih, 2005:21).

\section{TINJAUAN PUSTAKA}

Menurut Kartikahadi et al. (2012), pengertian akuntansi yaitu suatu sistem informasi keuangan, yang bertujuan untuk menghasilkan dan melaporkan informasi yang relevan bagi berbagai pihak yang berkepentingan sehingga dapat disimpulkan bahwa akuntansi adalah seni dalam mengukur, berkomunikasi dan menginterprestasikan aktivitas keuangan. Secara umum akuntansi juga dikenal sebagai "bahasa bisnis".

Menurut Fahmi (2011:2), kinerja keuangan adalah suatu analisis yang dilakukan untuk melihat sejauh mana suatu perusahaan telah melaksanakan dengan menggunakan aturan-aturan pelaksanaan keuangan secara baik dan benar. Kinerja perusahaan merupakan suatu gambaran tentang kondisi keuangan suatu perusahaan yang dianalisis dengan alat-alat analisis keuangan, sehingga dapat diketahui mengenai baik buruknya keadaan keuangan suatu perusahaan yang mencerminkan prestasi kerja dalam periode tertentu. Hal ini sangat penting agar sumber daya digunakan secara optimal dalam menghadapi perubahan lingkungan. Penilaian kinerja keuangan merupakan salah satu cara yang dapat dilakukan oleh pihak manajemen agar dapat memenuhi kewajibannya terhadap para penyandang dana dan juga untuk mencapai tujuan yang telah ditetapkan oleh perusahaan. Menurut Munawir (2012:31) tujuan penilaian kerja adalah sebagai berikut:

1. Untuk mengetahui tingkat likuiditas yaitu kemampuan perusahaan untuk memperoleh kewajiban keuangannya yang harus segera dipenuhi atau kemampuan perusahaan untuk memenuhi keuangannya pada saat ditagih.

2. Untuk mengetahui tingkat solvabilitas yaitu kemampuan perusahaan untuk memenuhi kewajiban keuangannya apabila perusahaan tersebut dilikuidasi, baik kewajiban keuangan jangka pendek maupun jangka panjang.

3. Untuk mengetahui tingkat rentabilitas atau profitabilitas yaitu menunjukkan kemampuan perusahaan untuk menghasilkan laba selama periode tertentu.

4. Untuk mengetahui tingkat stabilitas usaha yaitu kemampuan perusahaan untuk melakukan usahanya dengan stabil, yang diukur dengan mempertimbangkan kemampuan perusahaan untuk membayar beban bunga atas hutang-hutangnya termasuk membayar kembali pokok 
hutangnya tepat pada waktunya serta kemampuan membayar dividen secara teratur

kepada para pemegang saham tanpa mengalami hambatan atau krisis keuangan.

Menurut Kasmir (2008:7), laporan keuangan adalah laporan yang menunjukkan kondisi keuangan perusahaan pada saat ini atau dalam suatu periode tertentu. Munawir (2010:5) menyatakan bahwa pada umumnya laporan keuangan itu terdiri dari neraca dan perhitungan laba rugi serta laporan perubahan ekuitas. Menurut Harahap (2009:105), laporan keuangan menggambarkan kondisi keuangan dan hasil usaha suatu perusahaan pada saat tertentu atau jangka waktu tertentu. Menurut Pernyataan Standar Akuntansi Keuangan (PSAK) 2018 No. 1 paragraf ke 7 (revisi 2009), laporan keuangan adalah suatu penyajian terstruktur dari posisi keuangan dan kinerja keuangan suatu entitas.

Menurut Mokodompit et al. (2014), rasio derajat desentralisasi kinerja keuangannya masih kurang, rasio ketergantungan keuangan daerah terhadap pemerintah pusat dan provinsi masih sangat tinggi, begitu juga dengan rasio kemandiriannya masih sangat rendah. Saran untuk pemerintah Kota Kotamobagu sebagaimana lebih meningkatkan Pendapatan Asli Daerah (PAD) melalui penerimaan sektor pajak dan retribusi daerah.

Erica (2018) melakukan penelitian untuk melihat kondisi perusahaan dengan menggunakan rasio keuangan pada bulan September 2016, dimana analisis kondisi perusahaan dinilai dengan menggunakan pengukuran rasio likuiditas, rasio leverage, rasio aktivitas, rasio profitabilitas, menunjukkan bahwa perusahaan memiliki kemampuan untuk melunasi kewajiban pada kreditur.

Menurut Kaunang (2013), hasil analisis secara umum berdasarkan rasio keuangan yaitu posisi likuiditas dalam keadaan baik dalam hal perhitungan rasio lancar (current ratio) dan rasio cepat (quick ratio), akan tetapi pada rasio kas (cash ratio) perusahaan masih kurang dimana uang kas yang dimilki perusahaan belum mampu melunasi utang perusahaan. Rasio solvabilitas dapat dilihat bahwa hanya rasio hutang terhadap modal (debt to asset ratio/rasio hutang terhadap asset) yang cukup meningkat, dan untuk perhitungan rasio hutang terhadap modal (debt to equity ratio) mengalami penurunan. Hal ini disebabkan perusahaan belum mampu dalam mengelola keuangan yang ada. Selanjutnya untuk rasio rentabilitas, perusahaan mengalami penurunan, dimana keuntungan yang dimiliki oleh perusahaan sangatlah rendah dan berdampak kepada kebangkrutan perusahaan. Menurut Sipahelut et al. (2017), PT. Selamat Sempurna memiliki kinerja keuangan yang paling baik bila dibandingkan dengan Perusahaan sub Sektor Otomotif dan Komponen lainnya.

\section{METODE PENELITIAN}

Penelitian ini merupakan penelitian deskriptif, yaitu dengan cara mengumpulkan, mengklasifikasikan, menganalisis, dan menginterprestasikan data-data yang diperoleh dari perusahaan sehingga dapat memberikan gambaran dengan keadaan yang sebenarnya. Sugiyono (2016:63) menyebutkan bahwa dalam penelitian kualitatif pengumpulan data dilakukan pada kondisi yang alamiah (natural setting), sumber data primer, dan teknik pengumpulan data lebih banyak pada peran observasi (participant observation), wawancara mendalam (in depth interview) dan dokumentasi.

Menurut Hidayat (2010) penelitian deskriptif merupakan metode penelitian yang digunakan untuk menemukan pengetahuan yang seluas-luasnya terhadap objek penelitian pada suatu masa tertentu. Sedangkan menurut Punaji (2010) penelitian deskriptif adalah penelitian yang tujuannya untuk menjelaskan atau mendeskripsikan suatu peristiwa, keadaan, objek apakah orang, atau segala sesuatu yang terkait dengan variabel-variebel yang bisa dijelaskan baik menggunakan angka-angka maupun kata-kata.

Penelitian ini menggunakan metode deskriptif yaitu metode yang mengumpulkan, merumuskan dan mengklasifikasi serta menginterpretasikan data yang diperoleh dengan analisis data kuantitatif yang disajikan dalam bentuk angka yaitu yang berkaitan dengan 
analisis rasio likuiditas, solvabilitas, dan profitabilitas Hotel Sahid Kawanua Manado untuk tahun 2017-2018, sehingga menghasilkan gambaran yang jelas tentang kondisi sebenarnya perusahaan tersebut.

\section{HASIL PENELITIAN DAN PEMBAHASAN}

\subsection{Hasil penelitian}

Analisis rasio likuiditas. Tingkat likuiditas suatu perusahaan menunjukkan seberapa besar kemampuan perusahaan menggunakan modalnya untuk menghasilkan keuntungan dalam periode tertentu. Untuk menganalisis tingkat likuiditas pada Hotel Sahid Kawanua Manado, maka penelitian ini menggunakan laporan keuangan selama dua periode yaitu dari tahun 2017-2018.

Tabel 1. Rasio lancar (current rasio) pada Hotel Sahid Kawanua Manado tahun 20172018

\begin{tabular}{cccc}
\hline Tahun & Aktiva lancar & Hutang lancar & Rasio lancar \\
\hline 2017 & 5.173 .157975 & 2.833 .477 .465 & $182 \%$ \\
2018 & 6.057 .235 .469 & 3.003 .770 .609 & $201 \%$ \\
\hline
\end{tabular}

Sumber: data diolah, 2019

Tabel 1 menunjukkan bahwa rasio lancar perusahaan pada tahun 2017 adalah sebesar $182 \%$ merupakan hasil perbandingan asset lancar dengan kewajiban lancar untuk memenuhi kewajiban jangka pendek perusahaan. Dapat diinterpretasikan bahwa setiap Rp. 100,00 kewajiban lancar dijamin dengan 182\% asset lancar. Tahun 2018 rasio lancar perusahaan sebesar 201\%, dan dapat diinterpetasikan bahwa setiap Rp. 100,00 kewajiban lancar dijamin dengan 201\% asset lancar. Rasio lancar pada tahun 2018 lebih baik dibanding tahun 2017 karena terjadi peningkatan sebesar 19\%. Maka rasio lancar tahun 2018 lebih baik dibanding tahun 2017.

Analisis rasio solvabilitas. Rasio solvabilitas menggambarkan kemampuan perusahaan dalam membayar kewajiban jangka panjang atau kewajiban-kewajiban apabila perusahaan mengalami likuidasi.

Tabel 2. Total debt to asset ratio Hotel Sahid Kawanua Manado tahun 2017-2018

\begin{tabular}{cccc}
\hline Tahun & Total hutang & Total aktiva & $\begin{array}{c}\text { Rasio hutang terhadap total } \\
\text { aktiva }\end{array}$ \\
\hline 2017 & 27.857 .477 .488 & 33.516 .694 .382 & $83.11 \%$ \\
2018 & 25.021 .684 .697 & 32.607 .949 .641 & $76.73 \%$ \\
\hline
\end{tabular}

Sumber: data diolah, 2019

Tabel 2 menunjukkan bahwa Debt to Total Assets Ratio (DAR) pada tahun 2017 Hotel Sahid Kawanua Manado adalah sebesar $83.11 \%$. Ini berarti $83.11 \%$ total asset yang dimiliki oleh perusahaan dibelanjai dengan kewajiban. Kemudian pada tahun 2018, Debt to Total Assets Ratio (DAR) perusahaan adalah sebesar $76.73 \%$. Ini berarti $76.73 \%$ total asset yang dimiliki oleh perusahaan dibelanjai dengan kewajiban. Total Debt to Total Asset Ratio pada tahun 2018 mengalami peningkatan sebesar 6.38\% dibanding tahun 2017. Dengan demikian Total Debt to Total Asset Ratio pada tahun 2018 adalah lebih baik dibanding dengan tahun 2017. Debt to Equity Ratio pada tahun 2017 Hotel Sahid Kawanua Manado adalah sebesar $492 \%$, yang berarti $492 \%$ ekuitas perusahaan dibiayai dengan kewajiban. Kemudian pada tahun 2018 Debt to Equity Ratio Hotel Sahid Kawanua Manado adalah sebesar 329\% yang berarti $329 \%$ ekuitas perusahaan juga dibiayai dengan kewajiban. Debt to Equity Ratio 
perusahaan pada tahun 2018 mengalami peningkatan yang cukup signifikan, yakni sebesar $163 \%$ dibanding tahun 2017. Hal ini dikarenakan total kewajiban lebih besar dibanding dengan ekuitas yang dimiliki oleh perusahaan pada tahun 2017, dimana seharusnya tidak terlalu tinggi, karena semakin tinggi rasio ini maka semakin besar resiko kebangkrutan yang ditanggung oleh perusahaan. Debt to Equity Ratio tahun 2018 adalah lebih baik dibanding dengan tahun 2017.

\section{Analisis profitabilitas}

Retained earnings/total asset (RETA). Variabel ini merupakan variabel yang mengukur profitabilitas perusahaan secara kumulatif selama perusahaan berdiri. Variabel ini dihitung dengan cara sebagai berikut: RETA = retained earnings / total asset. Dari rumus di atas, maka Tabel 3 menunjukkan nilai Retained Earnings (RETA) Hotel Sahid Kawanua Manado dari tahun 2017-2018.

Tabel 3. Nilai rasio RETA Hotel Sahid Kawanua Manado tahun 2017-2018

\begin{tabular}{cccc}
\hline Tahun & Laba ditahan & Total aktiva (Rp) & RETA \\
\hline 2017 & 423.000 .000 & 33.516 .694 .381 & 0.012 \\
2018 & 1.439 .193 .159 & 32.606 .949 .641 & 0.044 \\
\hline
\end{tabular}

Sumber: data diolah, 2019

EBITTA (Earnings before interest and taxes/total asset). Variabel ini merupakan variabel yang mengukur profitabilitas perusahaan. Earnings beforeinterest and taxes (EBITTA) diperoleh dari laporan laba rugi, sedangkan total aset diperoleh dari neraca perusahaan. Dari rumus di atas, maka Tabel 4 menunjukkan nilai Earnings before interest and taxes (EBITTA) Hotel Sahid Kawanua Manado dari Tahun 2017-2018.

Tabel 4. Nilai rasio EBITTA Hotel Sahid Kawanua tahun 2017-2018

\begin{tabular}{cccc}
\hline Tahun & EBIT $(\mathbf{R p})$ & Total aktiva $(\mathbf{R p )}$ & EBITTA \\
\hline 2017 & 3.438 .098 .658 & 33.516 .694 .381 & 0.1025 \\
2018 & 4.094 .410 .013 & 32.606 .949 .641 & 0.1255 \\
\hline
\end{tabular}

Sumber: data diolah (2019)

\subsection{Pembahasan}

Pada rasio lancar setiap Rp. 100,00 kewajiban lancar dijamin dengan 201\% asset lancar. Rasio lancar pada tahun 2018 lebih baik dibanding tahun 2017 karena terjadi peningkatan sebesar 19\%. Maka rasio lancar pada tahun 2018 masih lebih baik dibanding tahun 2017. Rasio cepat pada tahun 2017 Hotel Sahid Kawanua Manado adalah sebesar $169 \%$ yang dapat diartikan bahwa setiap Rp 100,00 kewajiban dijamin dengan $169 \%$ asset lancar. Tahun 2018 rasio cepat perusahaan adalah sebesar 199\% yang berarti setiap Rp. 100,00 kewajiban dijamin dengan 199\% asset lancar yang cepat diuangkan. Rasio cepat pada tahun 2018 mengalami peningkatan, dimana rasio cepat mengalami peningkatan sebesar $30 \%$ dibanding tahun 2017. Sehingga dapat dikatakan bahwa rasio cepat pada Hotel Sahid Kawanua Manado tahun 2018 lebih baik dibanding tahun 2017.

Debt to Total Assets Ratio (DAR) pada tahun 2017 Hotel Sahid Kawanua Manado adalah sebesar $83.11 \%$. Ini berarti $83.11 \%$ total asset yang dimiliki oleh perusahaan dibelanjai dengan kewajiban. Kemudian pada tahun 2018 Debt to Total Assets Ratio (DAR) perusahaan adalah sebesar $76.73 \%$. Ini berarti $76.73 \%$ total asset yang dimiliki oleh perusahaan dibelanjai dengan kewajiban. Total Debt to Total Asset Ratio pada tahun 2018 mengalami peningkatan sebesar 6.38\% dibanding tahun 2017. Dengan demikian Total Debt to Total Asset Ratio pada tahun 2018 adalah lebih baik dibanding dengan tahun 2017. 
Sedangkan Debt to Equity Ratio pada tahun 2017 Hotel Sahid Kawanua Manado adalah sebesar $492 \%$, yang berarti $492 \%$ ekuitas perusahaan dibiayai dengan kewajiban. Kemudian pada tahun 2018 Debt to Equity Ratio Hotel Sahid Kawanua Manado adalah sebesar 329\% yang berarti $329 \%$ ekuitas perusahaan juga dibiayai dengan kewajiban. Debt to Equity Ratio perusahaan pada tahun 2018 mengalami peningkatan yang cukup signifikan, yakni sebesar 163\% dibanding tahun 2017. Hal ini dikarenakan total kewajiban lebih besar dibanding dengan ekuitas yang dimiliki oleh perusahaan pada tahun 2017, dimana seharusnya tidak terlalu tinggi, karena semakin tinggi rasio ini maka semakin besar resiko kebangkrutan yang ditanggung oleh perusahaan. Debt to Equity Ratio pada tahun 2018 adalah lebih baik dibanding dengan tahun 2017.

Analisis profitabilitas terdiri dari Retained earnings (RETA) dan Earnings before interest andtaxes (EBBITA) nilai rasio Retained earnings (RETA) pada tahun 2018 mengalami peningkatan, yang sebelumnya pada tahun 2017 sebesar 0.012 , sedangkan nilai rasio Earnings before interest and taxes (EBBITA) mengalami peningkatan pada tahun 2018 menjadi 0.1225 yang sebelumnya pada tahun 2017 rasio Earnings before interest and taxes (EBBITA) sebesar 0.1025.

\section{KESIMPULAN DAN SARAN}

\subsection{Kesimpulan}

Berdasarkan analisis yang telah dilakukan terhadap data Hotel Sahid Kawanua Manado maka diperoleh beberapa kesimpulan sebagai berikut:

1. Hasil analisis rasio antara tahun 2017-2018 menunjukkan hasil yang baik. Hal tersebut dideteksi dari peningkatan dari beberapa parameter kinerja keuangan. Diantaranya rasio likuiditas dan rasio solvabilitas yang meningkat.

2. Analisis profitabilitas berdasarkan analisis rasio RETA dan EBITTA mengalami peningkatan dari 2 tahun terakhir yaitu dari 2017 sampai 2018 yaitu rasio Retained earnings (RETA) pada tahun 2018 mengalami peningkatan dengan angka 0,044 yang sebelumnya pada tahun 2017 sebesar 0.012 dan sedangkan nilai rasio Earnings before interest and taxes (EBBITA) mengalami peningkatan pada tahun 2018 menjadi 0.1225 yang sebelumnya pada tahun 2017 rasio Earnings before interest and taxes (EBBITA) sebesar 0.1025 .

\subsection{Saran}

1. Penelitian selanjutnya dapat mengkaji tahun berikutnya mengenai Kinerja Keuangan yang ada di Hotel Sahid Kawanua Manado dengan mengukur dengan analisis likuiditas, solvabilitas, dan profitabilitas.

2. Penelitian selanjutnya diharapkan mengambil sebagai referensi dalam penelitian ini yaitu tentang analisis kinerja keuangan di Hotel Sahid Kawanua Manado dengan meneliti di tempat yang berbeda serta dapat mengembangkan hasil penelitian yang lebih baik dan akurat untuk kedepannya.

\section{DAFTAR PUSTAKA}

Erica, D. (2018). Analisa rasio laporan keuangan untuk menilai kinerja perusahaan PT. Kino Indonesia Tbk. Jurnal Ecodemica: Jurnal Ekonomi, Manajemen, dan Bisnis, 2(1), 12-20. https://ejournal.bsi.ac.id/ejurnal/index.php/ecodemica/article/view/2752

Fahmi, D. (2011). Analisa laporan keuangan. Bandung: Alfabeta.

Hanafih, M. M. (2005). Manajemen keuangan. Yogyakarta: Badan Penerbitan Fakultas Ekonomi.

Harahap, S. S. (2009). Teori kritis laporan keuangan. Jakarta: Bumi Aksara. 
Hidayat. A. A. A. (2010). Metode penelitian kesehatan paradigma kuantitatif. Jakarta: Heath Books.

Kaunang, A. (2013). Analisis kinerja keuangan perusahaan pada PT. Cipta Daya Nusantara Manado. Jurnal Riset Ekonomi Manajemen, Bisnis dan Akuntansi, 1(4), 1993-2003. https://ejournal.unsrat.ac.id/index.php/emba/article/view/3407

Kartikahadi, H., Sinaga, R. U., Syamsul, M., \& Siregar, S. V. (2012). Akuntansi keuangan berdasarkan SAK berbasis IFRS Buku 1. Jakarta: Salemba Empat.

Kasmir, (2008). Bank dan lembaga keuangan lainnya, Edisi Revisi 2008. Jakarta: PT. Rajagrafindo Persada.

Munawir, S. (2012). Analisis informasi keuangan. Yogyakarta: Liberty.

Munawir, S. (2010). Analisis laporan keuangan, Edisi 4, Cetakan 15. Yogyakarta: Liberty.

Mokodompit, P. S., Pangemanan, S. S., \& Elim, I. (2014). Analisis kinerja keuangan pemerintah daerah Kota Kotamobagu. Jurnal Riset Ekonomi Manajemen, Bisnis dan Akuntansi, 2(2),

1521-1527. https://ejournal.unsrat.ac.id/index.php/emba/article/view/4914

Punaji, S. (2010). Metode penelitian pendidikan dan pengembangannya. Jakarta: Kencana.

Ikatan Akuntan Indonesia. (2018). Standar Akuntansi Keuangan Revisi 2009.

Sugiyono. (2016). Metode penelitian kuantitatif, kualitatif dan R\&D. Bandung: PT. Alfabet.

Sipahelut, R. C., Murni, S., \& Rate, P. (2017). Analisis kinerja keuangan perusahaan (Studi kasus pada perusahaan sub sektor otmotif dan komponen yang terdaftar di BEI periode 2014-2016). Jurnal Riset Ekonomi Manajemen, Bisnis dan Akuntansi, 5(3) 4425-4434. https://ejournal.unsrat.ac.id/index.php/emba/article/view/18641

Tampubulon, M. (2005). Manajemen keuangan, Edisi Pertama. Jakarta: Ghalia Indonesia. 